\title{
Photovoltaic Performance of ZnO Nanorod and ZnO : CdO Nanocomposite Layers in Dye-Sensitized Solar Cells (DSSCs)
}

\author{
Sule Erten-Ela \\ Ege University, Solar Energy Institute, Bornova, 35100 Izmir, Turkey \\ Correspondence should be addressed to Sule Erten-Ela; suleerten@yahoo.com
}

Received 20 May 2013; Revised 8 August 2013; Accepted 4 September 2013

Academic Editor: Giuseppe Calogero

Copyright ( 2013 Sule Erten-Ela. This is an open access article distributed under the Creative Commons Attribution License, which permits unrestricted use, distribution, and reproduction in any medium, provided the original work is properly cited.

\begin{abstract}
Triphenylene diamine sensitizer comprising donor, electron conducting, and anchoring group is synthesized for a potential application in dye-sensitized solar cells. Absorption spectrum, electrochemical and photovoltaic properties of triphenylene diamine have been investigated. Two different electrodes are used for dye-sensitized solar cells. The performances of $\mathrm{ZnO}$ nanorod electrodes are compared to $\mathrm{ZnO}: \mathrm{CdO}$ nanocomposite electrode. Also, the theoretical calculations for HOMO and LUMO orbitals are used to estimate the photovoltaic properties of organic sensitizer in the design stage. $\mathrm{ZnO}$ : CdO nanocomposite electrode-based dyesensitized solar cell sensitized with organic sensitizer exhibits higher efficiencies than $\mathrm{ZnO}$ nanorod electrode. For a typical device, a solar energy conversion efficiency $(\eta)$ of 0.80 based on $\mathrm{ZnO}: \mathrm{CdO}$ nanocomposite is achieved under simulated AM 1.5 solar irradiation $\left(100 \mathrm{~mW} \mathrm{~cm}^{-2}\right)$ with a short circuit photocurrent density $\left(J_{\mathrm{sc}}\right)$ of $3.10 \mathrm{~mA} / \mathrm{cm}^{2}$, an open-circuit voltage $\left(V_{\mathrm{oc}}\right)$ of $480 \mathrm{mV}$, and a fill factor $(\mathrm{FF})$ of 0.57 . These results suggest that the $\mathrm{ZnO}$ : CdO nanocomposite system is a good selection and a promising candidate for electrode system in dye-sensitized solar cells.
\end{abstract}

\section{Introduction}

The modern society has intensively consumed energy resources, a large portion of which is accounted for by fossil fuel, such as petroleum, coal and natural gas. Development of alternative, renewable sources of energy is essential to reduce emission of carbon dioxide and other harmful substances when fossil fuel is burnt, as well as attain stable energy provision. Solar energy is one of several promising clean energy sources that could contribute to a stable energy supply and mitigate global environmental issues. In particular, the direct creation of electric energy is made possible through a solar cell. Much attention is now being focused on solar cells as potential energy-conversion systems. Dye sensitized nanocrystalline solar cells (DSSC) are of great interest as a cost-effective alternative to conventional silicon photovoltaics. The photoanode in DSSC is a mesoporous metal oxide film, sensitized by a monolayer of dye molecules. Upon visible light absorption, excited sensitizer molecules inject an electron into the conduction band of metal oxide. These carriers are transported and collected by a contact electrode $[1,2]$. Among the other metal oxides such as $\mathrm{SnO}_{2}, \operatorname{In}_{2} \mathrm{O}_{3}$, and $\mathrm{WO}_{3}, \mathrm{ZnO}$ nanostructures are promising materials for photovoltaic materials in solar cell. $\mathrm{ZnO}$ has large exiton binding energy $(60 \mathrm{MeV})$ with the $3.4 \mathrm{eV}$ energy band gap. Physical properties are similar to $\mathrm{TiO}_{2}$ but its electron mobility is higher by 2-3 orders of magnitude [3-5].

A sensitizer, as the light-harvesting component in a dyesensitized solar cell (DSSC), is of paramount importance to photovoltaic performance. The sensitizer is attached to the surface of a mesoporous wide band-gap semiconductor serving as electron transporter [6-8]. The interest in metalfree, organic dyes with high extinction coefficients has grown in recent years for organic solar cell research. In order to investigate organic dyes and, in the longer run, prepare an efficient solar cell dye, a number of different organic dyes are designed and synthesized [9-13]. Dye-sensitized solar cells (DSSCs) appear to be highly promising alternatives to more expensive solar cell technologies. Considering the current maximal level of overall conversion efficiency $(\eta)$ under simulated sunlight for DSSCs (12\%), improvements in efficiency and durability would certainly facilitate widespread utilization of this technology. It is clear that there are a number of factors determining the efficiency of solar cells, 
but the structural and physical properties of the sensitizer are clearly important ones $[14,15]$.

In this study, triphenylene diamine-based organic sensitizer is synthesized for dye sensitized solar cell application. Theoretical calculations for HOMO and LUMO orbitals of triphenyl diamine sensitizer are used to estimate the photovoltaic properties of organic sensitizer. Electrochemical properties are also investigated. Dye sensitized solar cell is operated with $4 \mu \mathrm{m}$ thicknesses of $\mathrm{ZnO}$ nanorod electrode. To obtain the better efficiency in dye sensitized solar cell, $\mathrm{ZnO}$ : $\mathrm{CdO}$ nanocomposite structure is prepared. Efficiencies of $\mathrm{ZnO}$ : $\mathrm{CdO}$ nanocomposite-based dye sensitized solar cell are compared to $\mathrm{ZnO}$ nanorod-based dye sensitized solar cell. Results show that $\mathrm{ZnO}$ : $\mathrm{CdO}$ nanocomposite electrodes have higher efficiencies than $\mathrm{ZnO}$ nanorods. And $\mathrm{ZnO}$ : $\mathrm{CdO}$ nanocomposite electrodes are promising materials for dye sensitized solar cells.

\section{Experimental}

2.1. Materials. Tetraphenylbenzidine, triphenyl phosphine, $\mathrm{POCl}_{3}$, cyanoacetic acid, and piperidine are purchased from Aldrich. Solvents are of spectroscopic grade and are used without any further purification.

2.2. Synthesis and Characterization of Triphenylene Diamines. The synthesis of TPD dye is conducted in two steps with moderate yields. Tetraphenylbenzidine is supplied from Aldrich company. First reaction is the Vilsmeier reaction, to form aldehyde product.

In the second reaction, the aldehyde is condensed with cyanoacetic acid by means of the Knoevenagel reaction in the presence of piperidine to form the target compound of TPD.

\subsection{Synthesis and Characterization of TPD Dye}

2.3.1. Synthesis Method of TPD. Aldehyde product and acrylic acid product are synthesized in the following procedure.

(1) Step (synthesis of 4-[[4'-(diphenylamino)biphenyl-4$y l$ (phenyl)amino]benzaldehyde). $\mathrm{POCl}_{3}$ (1.36 mmol, $0.2 \mathrm{~g}$ ) is stirred in a two-necked flask at $0^{\circ} \mathrm{C}$ for 1 hour in dried DMF under argon atmosphere. After additional stirring for $1 \mathrm{~h}$ at room temperature, this solution is added to a stirred solution of $5 \mathrm{~g}(0.0097 \mathrm{~mol})$ of $\mathrm{N}, \mathrm{N}^{\prime}$-Bis(diphenyl)benzidine in $20 \mathrm{~mL}$ of 1,2 -dichloroethane. This reaction mixture is stirred for another hour at $60^{\circ} \mathrm{C}$ and allowed to cool to room temperature. Hereafter, the mixture is poured into a solution of $10 \mathrm{~g}$ sodium acetate in $100 \mathrm{~mL}$ water, and this mixture is extracted three times with dichloromethane. The combined organic layers are washed twice with water and dried over magnesium sulfate. After filtration and evaporation of the solvent, a yellow solid is obtained. The desired monoformylated product is isolated from this crude product by column chromatography using silica gel and solvent as the eluent, 4 -[[4 $4^{\prime}$-(diphenylamino)biphenyl-4-yl $]$ (phenyl)amino]benzaldehyde, yellow crystals; molecular structure is analysed with ${ }^{1} \mathrm{H}$ NMR spectrum. ${ }^{1} \mathrm{H}$ NMR
$\left(\mathrm{CDCl}_{3}\right)$ : (ppm), 9.83 (1H, s, -CHO), $7.71(2 \mathrm{H}, \mathrm{d}, \mathrm{Ar}-\mathrm{H}), 7.55$ $(2 \mathrm{H}, \mathrm{t}, \mathrm{Ar}-\mathrm{H}), 7.48$ (2H, t, Ar-H), $7.21(21 \mathrm{H}, \mathrm{m}, \mathrm{Ar}-\mathrm{H})$.

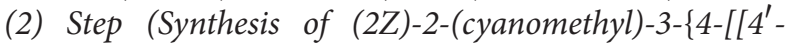
(diphenylamino)biphenyl-4-yl](phenyl)amino]phenyl\}acrylic acid, TPD). To a solution of 4 -[ [ $4^{\prime}$-(diphenylamino)biphenyl4-yl] (phenyl)amino]benzaldehyde $(0.16 \mathrm{mmol}, 72.3 \mathrm{mg})$ and cyanoacetic acid $(0.32 \mathrm{mmol}, 27.95 \mathrm{mg})$ in a mixture of tetrahydrofuran : methanol $(1: 1)$ is added catalytic amount of piperidine, after which the solution is stirred for $2 \mathrm{~h}$ at $40^{\circ} \mathrm{C}$. The solvent mixture is evaporated under reduced pressure and the resulting material is extracted with chloroform and $0.1 \mathrm{M} \mathrm{HCl}$ solution, washed with water, and dried over magnesium sulfate. The product is purified by column chromatography using silicagel and chloroform:methanol as the eluent. Molecular structure is characterized with IR and ${ }^{1} \mathrm{H}$ NMR spectrum, mass and elemantal analysis. IR $(\mathrm{KBr})$ : $\mathrm{cm}^{-1}, 3551,3412,3031,2214,1583,1487,1392,1323,1270,1178$, $1074,1028,1003,959,818,788,749,723,693,667 .{ }^{1} \mathrm{H}$ NMR $\left(\mathrm{DMSO}_{-} \mathrm{d}_{6}\right)$ : (ppm), $7.88(1 \mathrm{H}, \mathrm{s},-\mathrm{CH}=), 7.79(2 \mathrm{H}, \mathrm{d}, \mathrm{Ar}-\mathrm{H})$, $7.60(4 \mathrm{H}, \mathrm{q}, \mathrm{Ar}-\mathrm{H}), 7.36$ (6H, m, Ar-H), 7.15 (5H, m, Ar-H), $7.10(10 \mathrm{H}, \mathrm{m}, \mathrm{Ar}-\mathrm{H}) . \mathrm{MS} /(\mathrm{ESI} / 100 \mathrm{eV}): \mathrm{m} / z: 583 . \mathrm{C}_{40} \mathrm{H}_{29} \mathrm{~N}_{3} \mathrm{O}_{2}$ (583): Calcd: C 82.31\%, H 5.01\%, N 7.20\%, O 5.48\%; found: C $82.33 \%$, H 5.00\%, N 7.23\%, O 5.48\%.

Figure 1 shows the molecular structure of organic sensitizer. Absorption spectrum of TPD is taken in chlorobenzene solvent (Figure 2). It show that organic sensitizer absorbs in the visible region between $380-550 \mathrm{~nm}$.

2.4. Synthesis of ZnO Nanorods and CdO Nanostructures. $\mathrm{ZnO}$ nanorods and $\mathrm{CdO}$ nanostructures are synthesized from zinc salt and Cadmium salt in water solution using hydrothermal reaction. Microwave method is used fort he synthesis of $\mathrm{ZnO}$ and $\mathrm{CdO}$ nanostructures. In a typical experiment, zinc acetate is dissolved in $25 \mathrm{~mL}$ deionized water in a beaker. The concentration of zinc acetate dehydrate is $0.55 \mathrm{M}$. The solution is stirred with magnetic bar at $100^{\circ} \mathrm{C}$ for 1 hour until a transparent mixture is obtained. Subsequently, solution is loaded into a $100 \mathrm{~mL}$ Teflon-lined container. Then solution is irradiated by microwave energy in the microwave oven at $200^{\circ} \mathrm{C}$ for 60 minutes (CEM MARS-5, frequency $2.45 \mathrm{GHz}$, maximum power $700 \mathrm{~W}$, multimode oven). Then the solution is poured into a beaker and heated at $200^{\circ} \mathrm{C}$ until water is evaporated. After wet precipitate is dried in an oven at $90^{\circ} \mathrm{C}$ for $12 \mathrm{~h}$. Finally, white powder is calcined in a furnace at $200^{\circ} \mathrm{C}$ for 36 hours. For CdO synthesis, we followed the same experimental method using cadmium acetate dehydrate. White powder is calcined at $450^{\circ} \mathrm{C}$ for 36 hours. Brown $\mathrm{CdO}$ nanoparticles are obtained. To obtain $\mathrm{ZnO}: \mathrm{CdO}$ nanocomposite, $\mathrm{ZnO}$ is mixed with $5 \% \mathrm{CdO}$ nanostructures.

\section{Results and Discussion}

3.1. AFM Image of Thin Film of Organic Sensitizer. Morphology of organic material is another important factor for DSSCs. The surface morphology of thin film of triphenylene diamine is prepared in chlorobenzene solvent on FTO glass by using spin coater in $1500 \mathrm{rpm}$. Atomic force microscopy (AFM) 


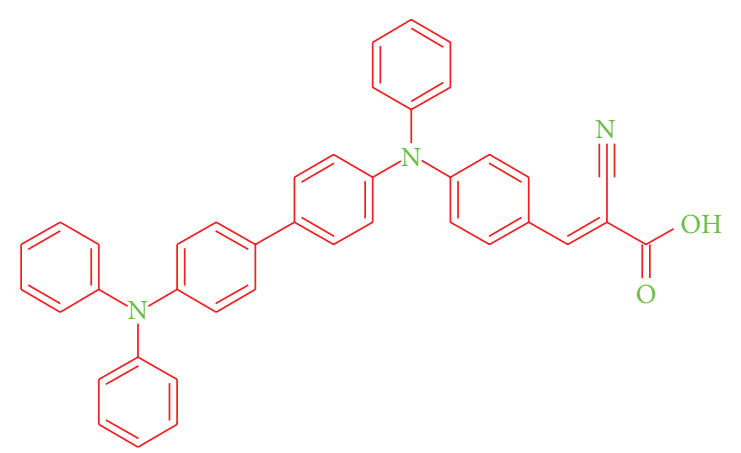

(Z)-2-Cyano-3-4-[4-(4-diphenylaminophenyl)(phenyl)anilino]phenyl-2-propenoic Acid, TPD

FIgURe 1: Molecular Structure of TPD Dye.

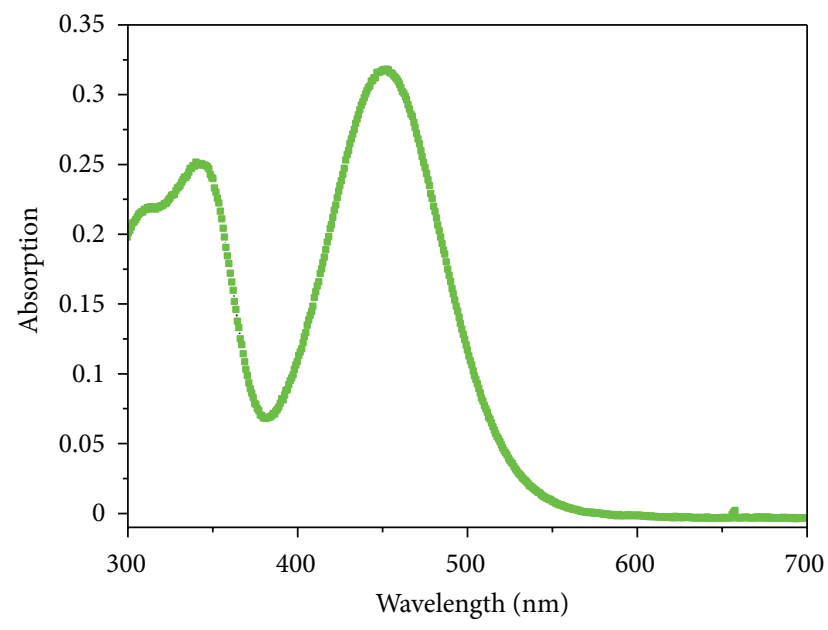

Figure 2: Absorption Spectrum of Organic Sensitizer in Chlorobenzene Solvent.

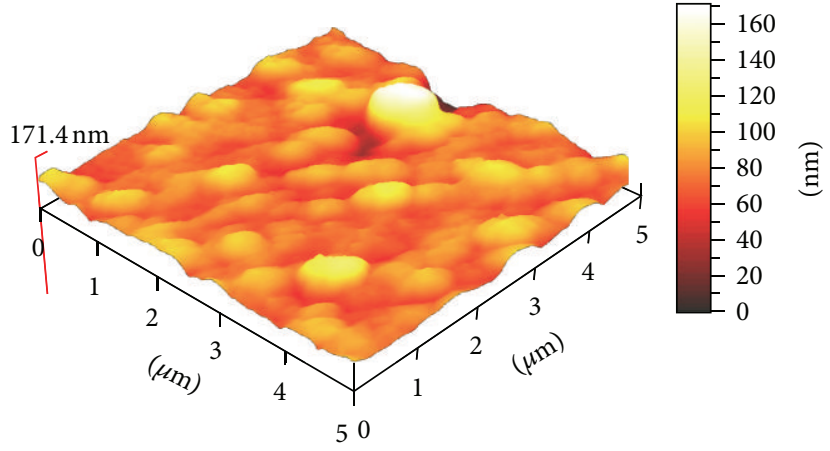

FIgure 3: Atomic Force Microscopy of Organic Sensitizer on FTO Glass.

image is taken in in noncontact mode (Figure 3). These measurements are performed under ambient conditions using a commercial scanning probe microscope. The AFM topographic image obtained is processed using the XEI program. Atomic force microscopy image of TPD which has $16.84 \mathrm{~nm}$ rms value is shown in Figure 3 on FTO glass.

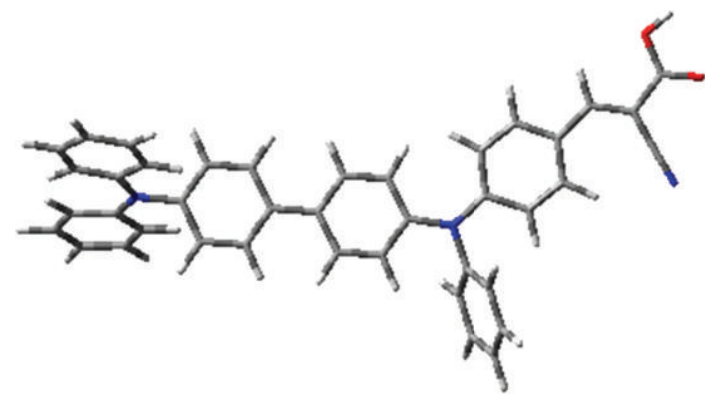

FIGURE 4: Ground State Optimization of Dye.

3.2. Theoretical Calculations of HOMO and LUMO Frontier Orbital of Organic Sensitizer. All ground-state geometry optimization and HOMO-LUMO orbital calculations are performed with the Gaussian 03 program package. Figure 4 shows the ground state optimization of organic dye. The HOMO is primarily comprised of $\pi$ framework of the triphenylene diamine, with significant contributions from $\pi$ electrons of the diphenylamino substituents (Figure 5(a)) whereas LUMO is very clearly confined to the $\pi$ system of anchoring group (Figure 5(b)).

3.3. SEM and XRD Analysis of $\mathrm{ZnO}$ and $\mathrm{ZnO}$ : CdO Nanoelectrodes. The crystal structures of the $\mathrm{ZnO}$ nanorods are investigated using XRD. The XRD pattern reveals that with the use of calcination method, $\mathrm{ZnO}$ nanorods are formed. The diffraction peaks positioned at $2 \theta$ values of $31.8,34.5,36.3$, $47.6,56.6,62.9,66.3,68.0,69.2,72.5$, and $76.9^{\circ}$ can be indexed to the hexagonal wurtzite phase of zinc oxide. The Nano-CdO materials are characterized using X-ray diffraction analysis (XRD). The XRD pattern shows the formation of nano-CdO materials. The diffraction peaks positioned at $2 \theta$ values of $32.9,38.2,55.2,65.8,69.2,81.9^{\circ}$ can be indexed to the phase of Cadmium oxide. Figure 6 shows the SEM images of $\mathrm{ZnO}$ nanorod (a) and $\mathrm{ZnO}$ : CdO nanocomposite (b).

3.4. Electrochemistry of Triphenylene Diamine Consisting of Anchoring Groups. $E_{\mathrm{HOMO}}$ and $E_{\mathrm{LUMO}}$ values of triphenylenediamine comprising anchoring groups are calculated by 


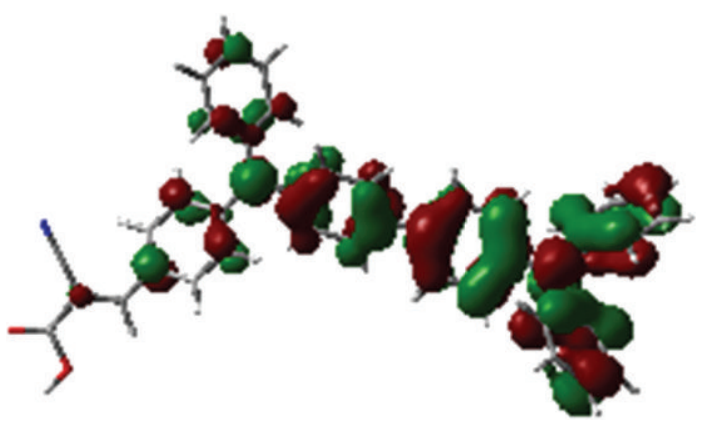

(a)

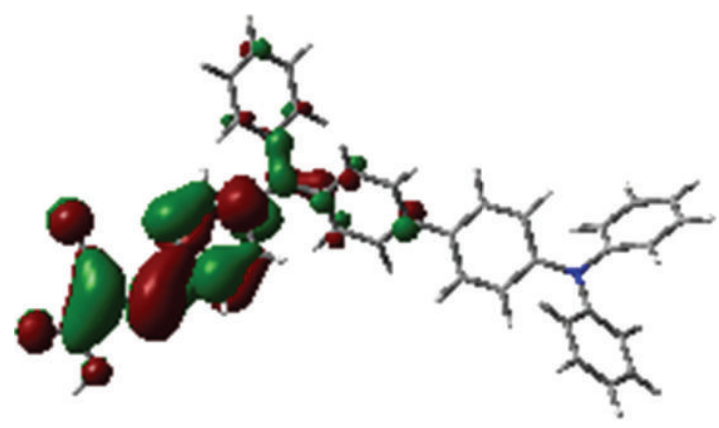

(b)

FIgURE 5: HOMO and LUMO Frontier Orbitals of Organic Sensitizer, HOMO Level (a), LUMO Level (b).

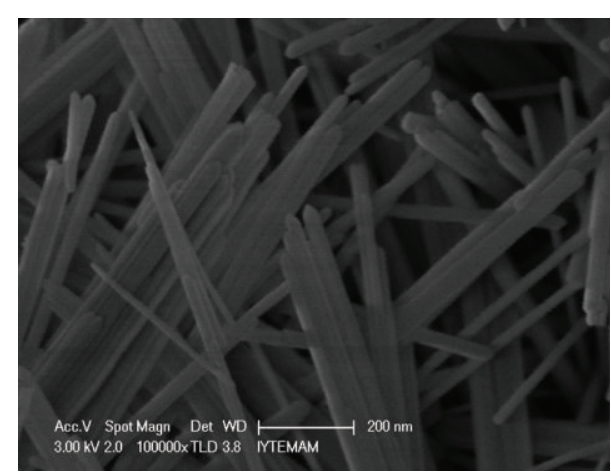

(a)

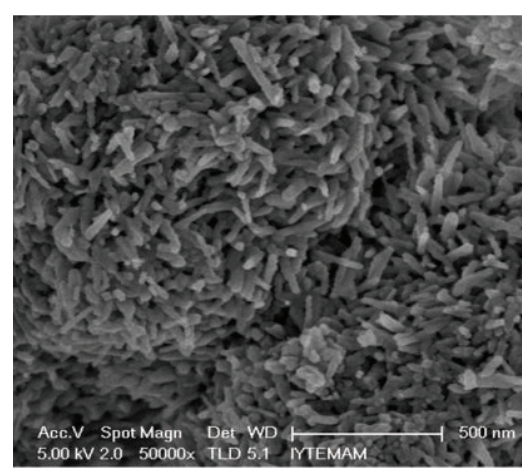

(b)

FIGURE 6: SEM image of $\mathrm{ZnO}$ nanorod (a) and $\mathrm{ZnO}$ : CdO nanocomposite (b).

using cyclic voltammograms. Solutions of TPD dye are prepared in dichloromethane $\left(10^{-3} \mathrm{M}\right)$. A three electrode cell set-up employed for the measurements consisted of glassy carbon working electrode, Pt wire counter electrode and $\mathrm{Ag} / \mathrm{AgCl}$ reference electrode, all placed in a glass vessel. Tetrabutylamonium hexafluorophosphate $\left(\mathrm{TBAPF}_{6}\right), 0.1 \mathrm{M}$, is used as supporting electrolyte. Ferrocene is used as internal reference electrode. Table 1 summarizes the voltammetric behavior of $10^{-3} \mathrm{M}$ solution of TPD. $E_{\text {HOMO }}$ and $E_{\mathrm{LUMO}}$ levels are calculated from the onset potentials of oxidation and reduction and by assuming the energy level of ferrocene/ferrocenium $\left(\mathrm{Fc} / \mathrm{Fc}^{+}\right)$to be $4.8 \mathrm{eV}$ below the vacuum level. Results shows that TPD sensitizer can inject electrons to conduction band of metaloxide semiconductor.

\subsection{Photovoltaic Device Fabrication and Characterization of} DSSCs. The construction of the dye sensitized solar cell device requires first cleaning of the fluorine doped tin oxide (FTO) coated glass substrates in a detergent solution using an ultrasonic bath for $15 \mathrm{~min}$, rinsed with water and ethanol. TPD has been used to manufacture solar cell devices to explore current-voltage characteristics using $4 \mu \mathrm{m}$ thickness of $\mathrm{ZnO}$ nanorod electrode and $4 \mu \mathrm{m} \mathrm{ZnO}$ : CdO nanocomposite electrode ( $\mathrm{ZnO}$ : 5\% CdO) for comparison to electrode efficiencies. Electrodes are immersed into the TPD solution $(0.5 \mathrm{mM}$ in a mixture of acetonitrile: tert-butanol; chlorobenzene (volume ratio: $1: 1: 3$ ) containing and kept
TABLE 1: Redox potentials of TPD derivatives.

\begin{tabular}{ccccccc}
\hline & $\begin{array}{c}E_{\text {oxidation }}{ }^{\mathrm{a}} \\
\text { (Volt) }\end{array}$ & $\begin{array}{c}E_{\text {reduction }}^{\mathrm{b}} \\
\text { (Volt) }\end{array}$ & $E_{\text {ferrocene }}{ }^{\mathrm{c}}{ }^{\mathrm{f}} E_{\text {HOMO }}{ }^{\mathrm{d}} E_{\text {LUMO }}{ }^{\mathrm{e}}$ & $E_{\text {Band Gap }}{ }^{\mathrm{f}}$ \\
\hline [TPD] & 0.85 & -1.08 & 0.39 & 5.26 & 3.33 & 1.93 \\
\hline
\end{tabular}

${ }^{\mathrm{a}}$ First oxidation potentials of TPD.

${ }^{\mathrm{b}}$ Reduction potentials of TPD.

${ }^{\mathrm{c}}$ Potentials of ferrocene, internal reference electrode.

${ }^{\mathrm{d}}$ HOMO energy level of TPD.

${ }^{\mathrm{e}}$ LUMO energy level of TPD.

${ }^{\mathrm{f}}$ Energy Band Gap of TPD.

at room temperature overnight. TPD adsorbed $\mathrm{ZnO}$ and $\mathrm{ZnO}$ : CdO coated glasses are washed with pure chlorobenzene. The stained electrode and Pt-counter electrode are assembled into a sealed sandwich-type cell by heating with a hot-melt ionomer film (Surlyn 1702, Du-Pont) as a spacer between the electrodes. Platinized FTO glasses are used as counter electrode. Platinization of counter electrodes is done by coating of FTO glasses with $1 \%$ solution of hydrogen hexachloroplatinate (Aldrich) in 2-propanol and annealing at $400^{\circ} \mathrm{C}$ for $30 \mathrm{~min}$. Cells are prepared in sandwich geometry. Surlyn 1702 (DuPont) frame is used as a spacer and a thermoplastic sealant between the two electrodes. Cells prepared in this way are then sealed by heating at $100^{\circ} \mathrm{C}$. A drop of electrolyte solution (electrolyte of $0.6 \mathrm{M} \mathrm{N}$-methyl-N-butylimidazolium iodide (BMII) $+0.1 \mathrm{M} \mathrm{LiI}+0.05 \mathrm{M} \mathrm{I}_{2}+0.5 \mathrm{M}$ 


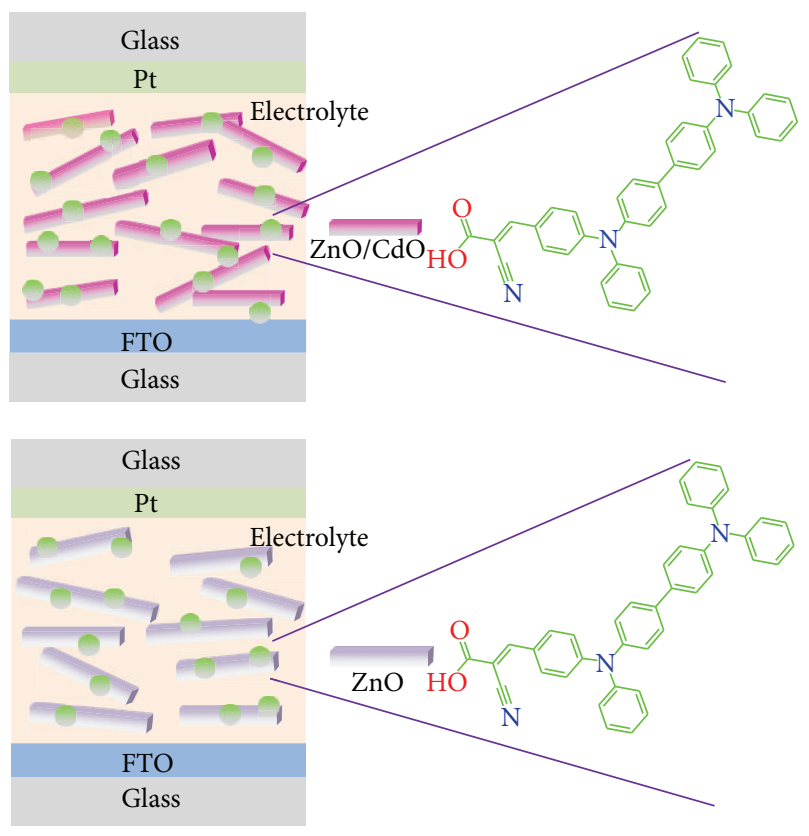

Figure 7: Schematic drawing of dye sensitized solar cells.

4-tert-butylpyridine (TBP) in acetonitrile) is placed on the drilled hole in the counter electrode of the assembled cell and is driven into the cell via vacuum backfilling. Finally, the hole is sealed using additional Bynel and a cover glass $(0.1 \mathrm{~mm}$ thickness). Active areas of the cells are adjusted to $1 \mathrm{~cm}^{2} . I-V$ data collection is made by using Keithley 2400 Sourcemeter and LabView data acquisition software. $I-V$ characteristics of dye sensitized solar cell in dark and under illumination are shown in Figure 6.

The entire energy conversion efficiency, $\eta$, is calculated by means of the following equations:

$$
\eta=\frac{V_{\mathrm{oc}} I_{\mathrm{sc}} \mathrm{FF}}{P_{\text {light }}},
$$

here, $V_{\mathrm{oc}}$ is open circuit voltage $(\mathrm{V}), I_{\mathrm{sc}}$ is short circuit current $\left(\mathrm{mA} / \mathrm{cm}^{2}\right)$, and FF is fill factor:

$$
\mathrm{FF}=\frac{V_{\mathrm{max}} I_{\max }}{V_{\mathrm{oc}} I_{\mathrm{sc}}},
$$

where, $V_{\max }$ and $I_{\max }$ are voltage and current at the point of maximum power output of cell.

Figure 7 shows the schematic illustration of dye sensitized solar cell.

3.6. Performance of Dye Sensitized Solar Cells. The TPD sensitizer has been used to manufacture solar cell devices to explore current-voltage characteristics by using $4 \mu \mathrm{m} \mathrm{ZnO}$ electrode and $4 \mu \mathrm{m} \mathrm{ZnO}: \mathrm{CdO}$ layers. Under standard global AM 1.5 solar conditions, the organic sensitizer is tested for other electrode using $4 \mu \mathrm{m} \mathrm{ZnO}$ nanorod and $4 \mu \mathrm{m}$ $\mathrm{ZnO}$ : $\mathrm{CdO}$ nanocomposite electrode for better comparison to electrode efficiency. Dye sensitized solar cell using $4 \mu \mathrm{m}$ $\mathrm{ZnO}$ nanorod electrode exhibits a short-circuit photocurrent
TABLE 2: Photovoltaic performance of $\mathrm{ZnO}$ and $\mathrm{ZnO}$ : CdO-based dye sensitized solar cells.

\begin{tabular}{lcccc}
\hline & $J_{\mathrm{sc}}\left(\mathrm{mAcm}^{-2}\right)$ & $V_{\mathrm{oc}}(\mathrm{mV})$ & $\mathrm{FF}$ & $\eta(\%)$ \\
\hline $\mathrm{ZnO}$ & 1.61 & 600 & 0.60 & 0.58 \\
$\mathrm{ZnO}: \mathrm{CdO}$ & 3.10 & 480 & 0.57 & 0.80 \\
$\mathrm{Z} 907$ & 11.54 & 772 & 0.66 & 5.72 \\
\hline
\end{tabular}

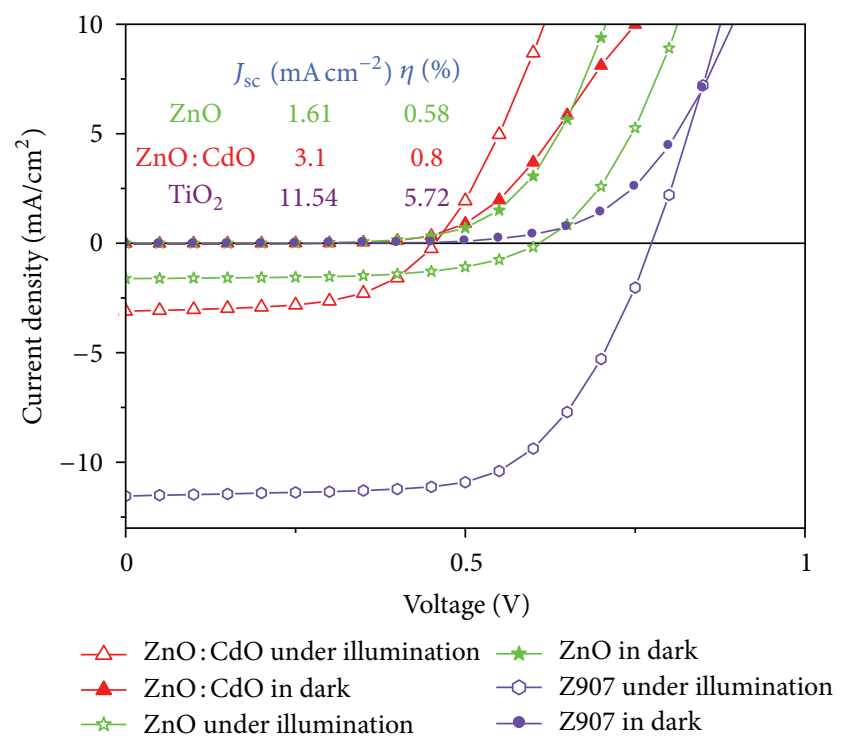

Figure 8: $J-V$ curve of $\mathrm{ZnO}$ and $\mathrm{ZnO}$ : CdO-based DSSCs.

density $\left(J_{\mathrm{sc}}\right)$ of $1.61 \mathrm{~mA} / \mathrm{cm}^{2}$, an open-circuit voltage $\left(V_{\mathrm{oc}}\right)$ of $600 \mathrm{mV}$, and a fill factor (FF) of 0.60 , corresponding to an overall conversion efficiency, $\eta$ of $0.58 \%$. Normally, $\mathrm{ZnO}$ has lower efficiency than $\mathrm{TiO}_{2}$ electrode because of $\mathrm{ZnO}$ crystal defects. Ruthenium Z907 gives higher efficiency in $\mathrm{TiO}_{2}$ with overall conversion efficiency of 5.72 and short circuit photocurrent density of $11.54 \mathrm{~mA} / \mathrm{cm}^{2}$ in our laboratory condition. For this reason, $n$-type $\mathrm{ZnO}$ is doped with $n$-type $\mathrm{CdO}$ nanomaterial to improve the crystal quality of $\mathrm{ZnO}$ nanorods. 5\% $\mathrm{CdO}$ nanostructures are mixed with $\mathrm{ZnO}$ nanorods to improve the crystal quality of $\mathrm{ZnO}$ nanorods. $4 \mu \mathrm{m} \mathrm{ZnO}$ : $\mathrm{CdO}$ nanocomposite electrode is used for improving the dye sensitized solar cell efficiency. We have tested several ratios of $\mathrm{ZnO}: \mathrm{CdO}$ composite, $\% 5 \mathrm{CdO}$ ratio is the optimum ratio for our experiments. $\mathrm{ZnO}$ : CdObased dye sensitized solar cell using TPD sensitizer gives a short-circuit photocurrent density $\left(J_{\mathrm{sc}}\right)$ of $3.10 \mathrm{~mA} / \mathrm{cm}^{2}$, an open-circuit voltage $\left(V_{\mathrm{oc}}\right)$ of $480 \mathrm{mV}$, and a fill factor $(\mathrm{FF})$ of 0.57 , corresponding to an overall conversion efficiency $\eta$ of $0.80 \%$. ZnO nanorod electrode shows lower efficiency than $\mathrm{ZnO}$ : CdO electrode. Figure 8 shows the $J-V$ curve of all dye sensitized solar cells. And all photovoltaic characterization results are shown in Table 2. Results show that $\mathrm{ZnO}: \mathrm{CdO}$ nanocomposite is a good selection and improves the solar cell efficiency. According to SEM images in Figure 6, $\mathrm{ZnO}$ morphology is completely changed after doping with $5 \%$ CdO. Crystal morphology effects the dye sensitized solar cell efficiency. 
In line with these statements, the higher efficiency is reported under standard conditions obtained for TPD sensitizer using $4 \mu \mathrm{m} \mathrm{ZnO}$ : $\mathrm{CdO}$ layers. $\mathrm{ZnO}$ : CdO nanocomposite-based solar cells shows remarkably good efficiencies according to $\mathrm{ZnO}$ nanorod for the application of DSSCs.

\section{Conclusion}

In this paper, we have successfully fabricated dye sensitized solar cells using $\mathrm{ZnO}$ nanorod electrode and $\mathrm{ZnO}: \mathrm{CdO}$ nanocomposite electrode. We report the good efficiency obtained with $4 \mu \mathrm{m} \mathrm{ZnO}$ : $\mathrm{CdO}$ layers under standard conditions for TPD dye that performs a short-circuit photocurrent density $\left(J_{\mathrm{sc}}\right)$ of $3.10 \mathrm{~mA} / \mathrm{cm}^{2}$, an open-circuit voltage $\left(V_{\mathrm{oc}}\right)$ of $480 \mathrm{mV}$, and a fill factor (FF) of 0.57 , corresponding to an overall conversion efficiency $\eta$ of $0.80 \%$. $\mathrm{ZnO}$ nanorodbased DSSC gives a short-circuit photocurrent density $\left(J_{\mathrm{sc}}\right)$ of $1.61 \mathrm{~mA} / \mathrm{cm}^{2}$, an open-circuit voltage $\left(V_{\mathrm{oc}}\right)$ of 600 , and a fill factor $(\mathrm{FF})$ of 0.60 , corresponding to an overall conversion efficiency $\eta$ of $0.58 \%$. As a conclusion, $\mathrm{ZnO}$ : $\mathrm{CdO}$ electrode exhibits higher efficiencies than $\mathrm{ZnO}$ nanorod electrode.

\section{Acknowledgment}

The author acknowledges the Alexander Von Humboldt Foundation and Scientific Research Council of Turkey (TUBITAK). The author thanks mechanical engineer Cagatay ELA for his unending support and valuable contribution to this paper.

\section{References}

[1] B. O’Regan and M. Grätzel, "A low-cost, high-efficiency solar cell based on dye-sensitized colloidal $\mathrm{TiO}_{2}$ films," Nature, vol. 353, no. 6346, pp. 737-740, 1991.

[2] M. Grätzel, "Photoelectrochemical cells," Nature, vol. 414, no. 6861, pp. 338-344, 2001.

[3] M. Grätzel, "Conversion of sunlight to electric power by nanocrystalline dye-sensitized solar cells," Journal of Photochemistry and Photobiology A, vol. 164, no. 1-3, pp. 3-14, 2004.

[4] M. K. Nazeeruddin, F. de Angelis, S. Fantacci et al., "Combined experimental and DFT-TDDFT computational study of photoelectrochemical cell ruthenium sensitizers," Journal of the American Chemical Society, vol. 127, no. 48, pp. 16835-16847, 2005.

[5] H. Imahori, T. Umeyama, and S. Ito, "Large $\pi$-aromatic molecules as potential sensitizers for highly efficient dye-sensitized solar cells," Accounts of Chemical Research, vol. 42, no. 11, pp. 1809-1818, 2009.

[6] Q. Zhang, C. S. Dandeneau, X. Zhou, and C. Cao, "ZnO nanostructures for dye-sensitized solar cells," Advanced Materials, vol. 21, no. 41, pp. 4087-4108, 2009.

[7] S. Kolemen, O. A. Bozdemir, Y. Cakmak et al., "Optimization of distyryl-Bodipy chromophores for efficient panchromatic sensitization in dye sensitized solar cells," Chemical Science, vol. 2, no. 5, pp. 949-954, 2011.

[8] S. Erten-Ela, S. Cogal, G. Turkmen, and S. Icli, "Hybrid solar cells using nanorod zinc oxide electrodes and perylene monoimide-monoanhydride dyes," Current Applied Physics, vol. 10, no. 1, pp. 187-192, 2010.
[9] S. Erten-Ela, S. Cogal, and S. Icli, "Conventional and microwave-assisted synthesis of $\mathrm{ZnO}$ nanorods and effects of PEG400 as a surfactant on the morphology," Inorganica Chimica Acta, vol. 362, no. 6, pp. 1855-1858, 2009.

[10] S. Erten-Ela and A. C. Cakir, "Comparison between synthesis techniques to obtain $\mathrm{ZnO}$ nanorods and its effect on dye sensitized solar cells," Advanced Powder Technology, vol. 23, pp. 655660, 2012.

[11] H. Sarica and S. Erten-Ela, "Photovoltaic characterizations of Nano-CdO based dye sensitized solar cells," Journal of Optoelectronics and Advanced Material, vol. 14, no. 9-10, pp. 753-757, 2012.

[12] S. Erten-Ela, J. Brendel, and M. Thelakkat, "Solid-state dyesensitized solar cells fabricated with nanoporous $\mathrm{TiO}_{2}$ and TPD dyes: analysis of penetration behavior and I-V characteristics," Chemical Physics Letters, vol. 510, no. 1-3, pp. 93-98, 2011.

[13] S. Erten-Ela, M. D. Yilmaz, B. Icli, Y. Dede, S. Icli, and E. U. Akkaya, "A panchromatic boradiazaindacene (BODIPY) sensitizer for dye-sensitized solar cells," Organic Letters, vol. 10, no. 15, pp. 3299-3302, 2008.

[14] P. A. Bouit, M. Marszalek, R. Humphry-Baker et al., "Donor-pAcceptors containing the 10-(1,3-Dithiol-2-ylidene)anthracene unit for dye-sensitized solar cells," European Journal of Chemistry, vol. 18, pp. 11621-11629, 2012.

[15] S. Feihl, R. D. Costa, S. Pflock et al., "Nickel oxide nanostructured electrodes towards perylenediimide-based dye-sensitized solar cells," RSC Advances, vol. 2, pp. 11495-11503, 2012. 

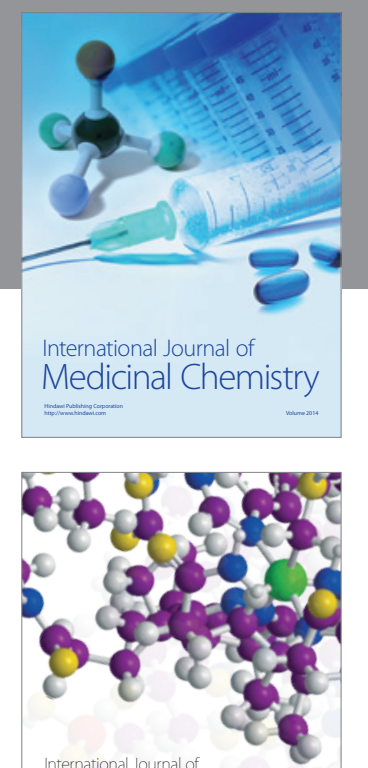

\section{Carbohydrate} Chemistry

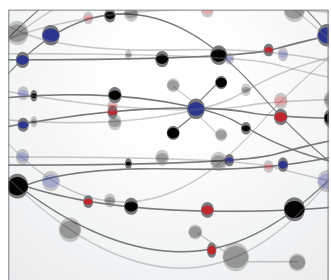

The Scientific World Journal
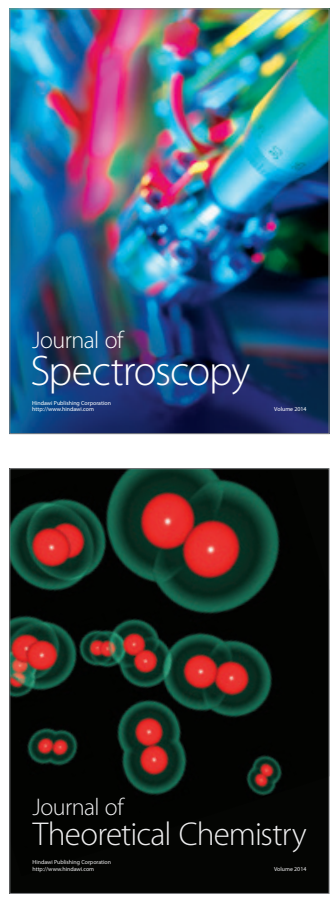
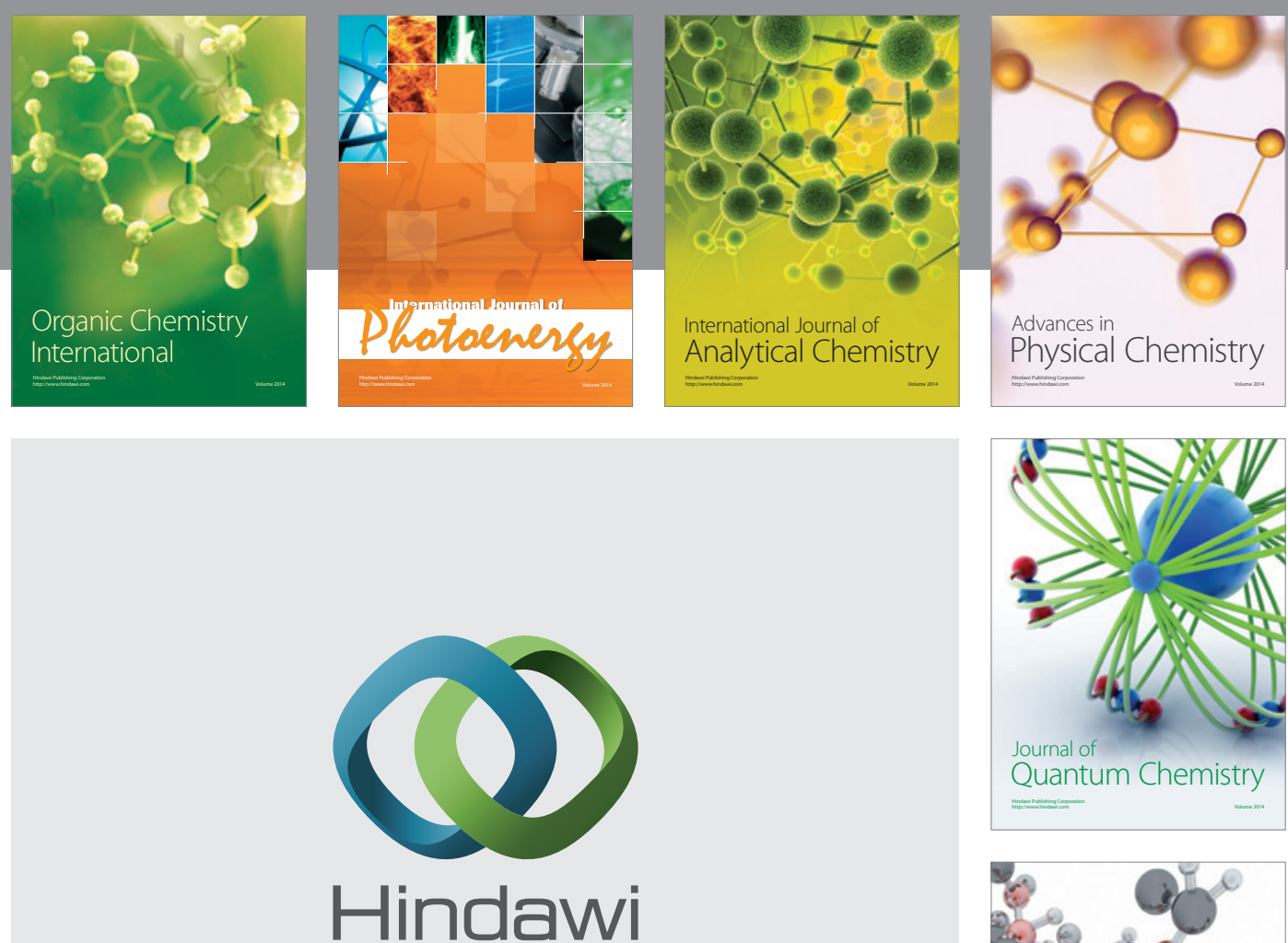

Submit your manuscripts at

http://www.hindawi.com

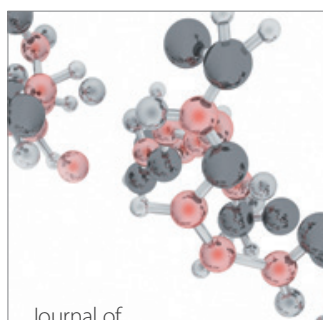

Analytical Methods

in Chemistry

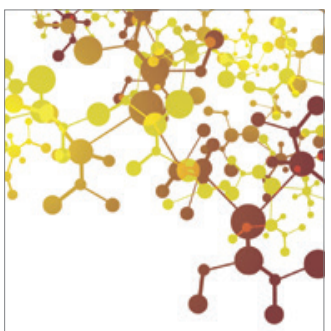

Journal of

Applied Chemistry

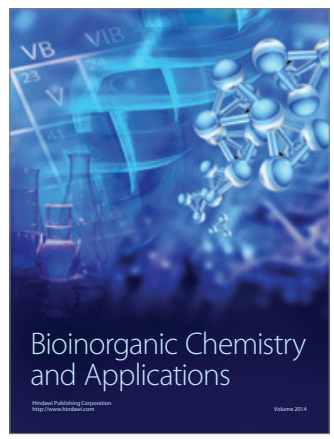

Inorganic Chemistry
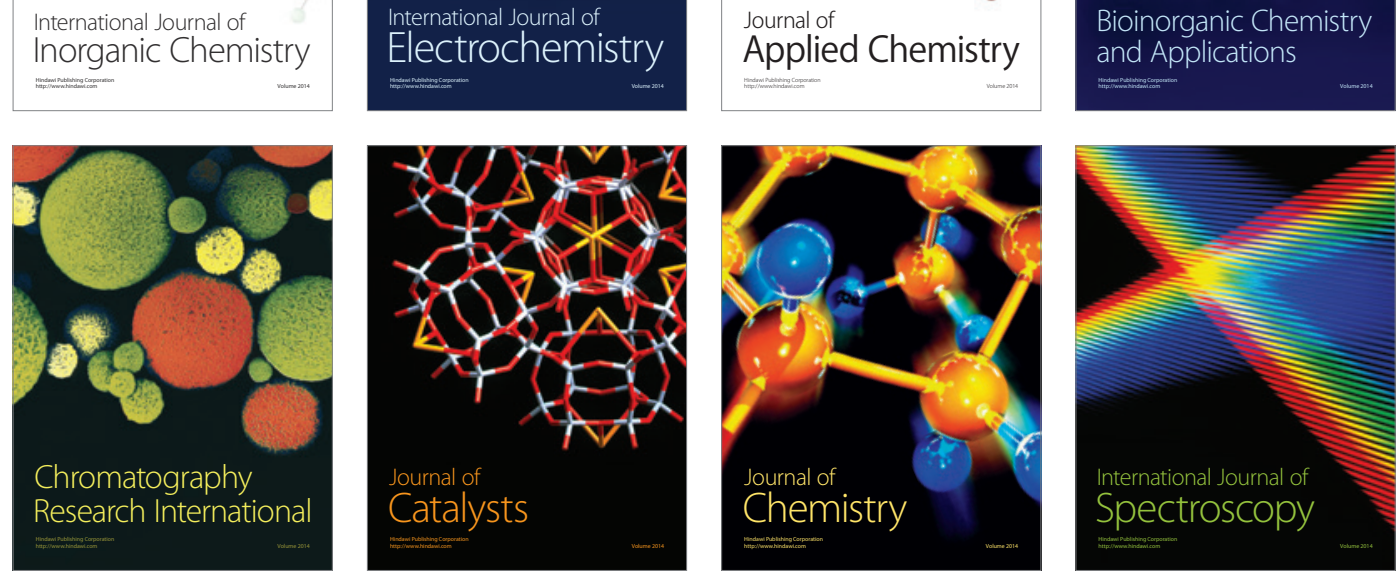